\title{
An investigation into the acute vascular effects of riveting
}

\author{
Kathleen M McKenna, S McGrann, A D Blann, Judith A Allen
}

\begin{abstract}
Measurements were made on 46 pairs of riveters and matched control subjects before and after a morning's work. Before starting work, the mean resting finger systolic pressure was 112 (SEM 3.3) $\mathrm{mm} \mathrm{Hg}$ in the riveters, similar to $117(1 \cdot 7)$ in the control subjects. After cooling the middle phalanx to $10^{\circ} \mathrm{C}$ for five minutes, 16 riveters but only one control subject exhibited digital vasospasm and these numbers were unaltered after a morning's work. A subgroup of riveters whose role was always to provide counter pressure to the rivet gun showed a higher incidence $(45 \%)$ of cold induced vasospasm than did riveters who invariably held the gun $(10 \%)$ or rotated between both roles $(27 \%)$. Plasma levels of three markers of vascular activity, endothelin-1 (ET-1), von Willebrand factor antigen (vWFAg), and angiotensin converting enzyme (ACE), were measured in non-smoking riveters and control subjects. Before work, ET-1 concentrations were slightly lower $(p<0.05)$ in the riveters, but vWFAg concentration and ACE activity were similar in riveters and control subjects. Riveting for a morning did not alter ET -1 concentration or ACE activity but did induce a small increase $(p<0.05)$ in vWFAg concentration, which may indicate damage to the endothelium. This type of vascular assessment may be helpful in assessing vasospastic complications in workers exposed to vibration.
\end{abstract}

\section{(British Journal of Industrial Medicine 1993;50:160-166)}

Occupational exposure to hand held vibrating tools can produce vasospastic disease in the fingers ("vibration white finger" or VWF). The vascular manifestations were first described by Loriga in

School of Biomedical Science (Physiology), The Queen's University of Belfast, Medical Biology Centre, 97 Lisburn Road, Belfast BT9 7BL

K M McKenna, S McGrann, J A Allen

Department of Surgery, University Hospital of South Manchester, Nell Lane, West Didsbury, Manchester M20 8LR

A D Blann
$1911,{ }^{1}$ but despite much research, the underlying mechanisms still remain unclear. Vibration white finger has been a prescribed industrial disease since 1985 and typically presents as episodic cold induced blanching of the digits. Initially only the tips of the digits are affected but the condition can progress if exposure to vibration is continued.

Measurement of finger systolic blood pressure (FSP) during cooling can be used as an objective test for vasospasm in Raynaud's phenomenon ${ }^{2}$ and has been reported to be both sensitive and specific. ${ }^{3}$ The sensitivity of this technique is low in mild VWF, ${ }^{4}$ but can be enhanced by additional cooling. ${ }^{5}$ Further modification to make measurements from the cutaneous vasculature produced a provocative cooling regime for the systematic investigation of digital vasospasm in the laboratory ${ }^{6}$ and this has been used in the assessment of VWF. ${ }^{7}$ In the first study described here, a simplified form of the test has been used in a factory environment to examine the acute vascular effects of riveting.

In a second study, the effects of riveting on the vascular endothelium were investigated by measuring the plasma levels of three different molecules with vasoactive relevance. Endothelin-1 (ET-1), a potent locally acting vasoconstrictor substance, is synthesised in the endothelium and the plasma concentrations have been reported to be higher in patients with Raynaud's syndrome than in control subjects. ${ }^{8}$ Von Willebrand factor antigen ( $\mathrm{vWFAg}$ ) is a specific product of the endothelium and its concentrations are raised in some conditions associated with injury or damage to blood vessels such as Raynaud's syndrome 9 or more severe inflammatory vascular disease. ${ }^{10}$ Raised concentrations have also been reported in patients with the hand-arm vibration syndrome. ${ }^{11}$ Angiotensin converting enzyme (ACE) is produced in the endothelium ${ }^{12}$ and was also measured in view of its role in the production of the powerful vasoconstrictor angiotensin II.

\section{Subjects and methods}

SUBJECTS

Measurements were made during the winter and early spring on 64 healthy male riveters, age range 20-55 (mean 32) and 52 male control subjects, age range 18-54 (mean 34). Anyone with a history of injury to the neck, trunk, or upper limbs was 
Table 1 Industrial population studied

\begin{tabular}{lcc}
\hline & $\begin{array}{l}\text { Riveters } \\
(n=46)\end{array}$ & $\begin{array}{c}\text { Controls } \\
(n=46)\end{array}$ \\
\hline Smokers & 16 & 16 \\
Mean age (range) (y) & $33(20-55)$ & $33(18-54)$ \\
Mean vibration exposure (range) $(y)$ & $7(0 \cdot 2-18)$ & 0 \\
\hline
\end{tabular}

Population: 64 riveters; 52 control subjects.

Subgroup: 46 riveters; 46 control subjects.

excluded. The occupational exposure to vibration of the riveters ranged from $0 \cdot 2-18$ years (mean $6 \cdot 2$ ), with $44 \%$ having less than 2.5 years of exposure due to recent recruitment. A further $28 \%$ had more than 10 years of exposure. The control subjects were machine operators who worked in the same environment as the riveters but had never used vibrating tools in their work and had no symptoms of peripheral vascular disease. The study was approved by the local ethical committee and all subjects gave informed consent.

A detailed medical and occupational history enabled a subgroup of 46 pairs of riveters and controls to be identified who were closely matched for age and smoking habit (table 1). It also showed that the riveters could be further subdivided into three groups depending on the precise work they do. They work in pairs; one man uses the rivet gun while his partner, the "dollyman," holds a toughened metal bar on the opposite side of the two pieces of metal being riveted together. Of the total of 64 riveters examined, 20 always used the gun, 22 were always dollymen, and 22 rotated between both jobs.

\section{MEASUREMENTS IN THE FIRST STUDY}

The subjects wore normal working clothes and lay supine on a couch in a room at $20-22^{\circ} \mathrm{C}$ with the hand supported at heart level. Measurements were made over a 30 minute period on the most affected finger of any man who reported symptoms of VWF, otherwise on the right middle finger. The measurements shown in table 2 were made before starting work in the morning, and three hours later within five minutes of stopping work. Outdoor temperature on arrival at work and ambient temperature at the workplace were also recorded.

Table 2 Measurements made before and after work

\begin{tabular}{ll}
\hline Environmental temperature & $\begin{array}{l}\text { Workplace } \\
\text { During measurements }\end{array}$ \\
On the subject & Mouth temperature \\
& Finger skin temperature (pulp) \\
& Finger systolic pressure: \\
& Resting $\times 3$ \\
After cooling \\
Brachial arterial pressure \\
Vibration perception threshold
\end{tabular}

The FSP was measured using laser Doppler flowmetry to monitor red cell flux in fingertip skin. ${ }^{6}$ Figure 1 shows the measurement of resting FSP with the finger in room air. Inflation of the cuff on the proximal phalanx to $200 \mathrm{~mm} \mathrm{Hg}$ abolished fingertip skin flux. During cuff deflation, the cuff pressure at which flux reappeared was taken as the FSP. Three measurements were made and the mean taken as resting FSP. The middle phalanx was then rapidly cooled by inserting the finger through a glass cuff perfused by water at $10^{\circ} \mathrm{C}$ (fig 2). Cooling of the middle phalanx was made more complete by the inflation of the proximal cuff to $200 \mathrm{~mm} \mathrm{Hg}$ thus preventing inflow of arterial blood. After five minutes of cooling FSP was measured again. Absence of flux after cooling indicated that complete vasospasm had occurred. A decrease in FSP after cooling to $50 \%$ or less of its resting value was taken to indicate partial vasospasm. The finger was then rewarmed to $32^{\circ} \mathrm{C}$.

Brachial systolic pressure was measured by auscultation over the brachial artery. Vibration perception thresholds were measured at the finger pulp and proximal interphalangeal and metacarpophalangeal joints using a biothesiometer (Bio-Medical Instrument Co, Ohio, USA).
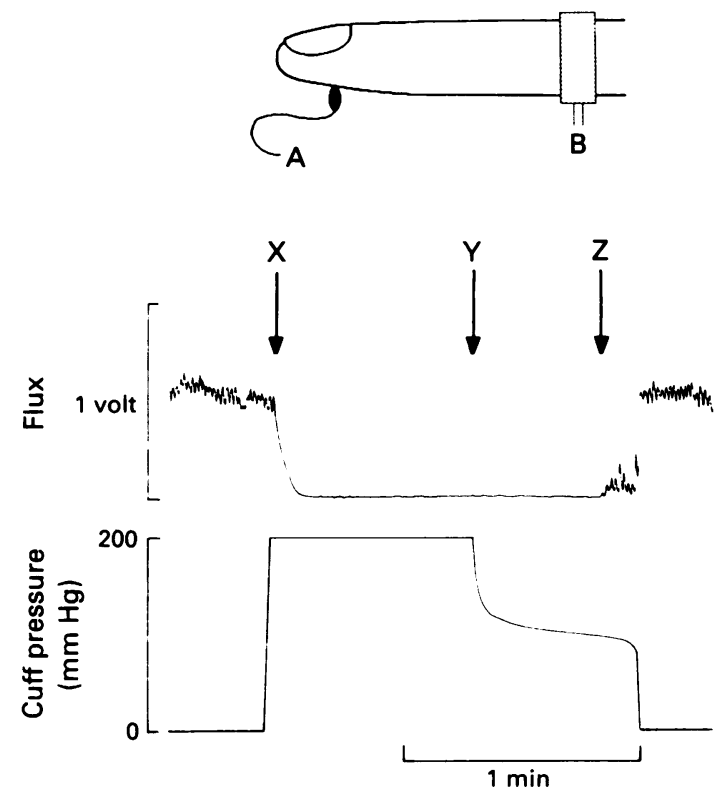

Figure 1 Measurement of resting finger systolic pressure. Upper trace shows flux in the fingertip skin recorded by the laser Doppler probe A. Lower trace shows pressure in cuff $B$ surrounding the proximal phalanx. At $X$ the cuff was inflated to $200 \mathrm{~mm} \mathrm{Hg}$ and flux was abolished. At Y gradual cuff deflation commenced and flux returned at $Z$ at a pressure of $98 \mathrm{~mm} \mathrm{Hg}$. 
MEASUREMENTS IN THE SECOND STUDY

These were carried out on a different day on those men from the first study who agreed to participate.

Venous blood samples were withdrawn from the antecubital vein of riveters and control subjects while relaxing supine in a room at $20-22^{\circ} \mathrm{C}$. Sampling took place before starting work in the morning and again within five minutes of stopping three hours later. The blood was drawn into chilled tubes containing $7 \cdot 5$ $\mathrm{mM}$ ethylenediaminetetraacetic acid, centrifuged immediately for 15 minutes at $4^{\circ} \mathrm{C}$ to separate plasma, and stored at $-70^{\circ} \mathrm{C}$ until analysis. Samples were transported in dry ice and analysed blind. Plasma vWFAg concentrations are raised in smokers, ${ }^{13}$ so only results from the plasma of non-smokers were compared. These came from 25 riveters and 24 controls.

\section{Endothelin-1 assay}

Concentrations of ET-1 were determined by radioimmunoassay (endothelin $1-21$ specific [ [ $\left.{ }^{125} 1\right]$ assay system, Amersham, UK).

von Willebrand factor antigen assay

Concentrations of vWFAg were estimated by an established enzyme linked immunosorbent assay method in 96 well microtitre plates with commercial antisera. ${ }^{10}$

\section{Angiotensin converting enzyme assay}

Activity of ACE was assayed by an enzymatic spectrophotometric technique with a specific substrate. ${ }^{14}$

\section{STATISTICAL ANALYSIS}

The results were analysed with the Wilcoxon signed rank test for paired data (first study) and the MannWhitney $U$ test for unpaired data (second study).

\section{Results}

FIRST STUDY: COMPARISON OF RIVETERS WITH CONTROL SUBJECTS

Figure 2 shows recordings before and after cooling the middle finger of a control subject whose resting FSP was $98 \mathrm{~mm} \mathrm{Hg}$. After five minutes of middle phalangeal cooling and occlusion, FSP was 102 mm Hg.

Figure 3 shows recordings from the middle finger of a riveter who complained of cold induced blanching of his fingers. His resting FSP was $97 \mathrm{~mm} \mathrm{Hg}$. After middle phalangeal cooling there was no return of flux as the proximal pressure cuff was gradually deflated; FSP after cooling was $0 \mathrm{~mm} \mathrm{Hg}$.

On quesioning, eight of the 46 paired riveters had finger symptoms and none of the 46 controls admitted to any problems. Before commencing work in the morning, 16 riveters and one control subject

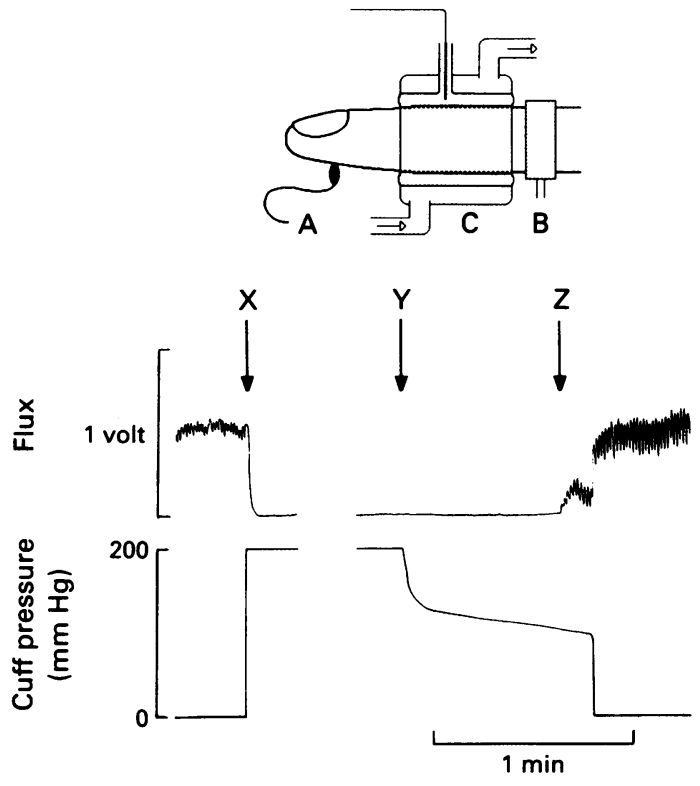

Figure 2 Measurement of response to cooling in a control finger. Upper trace shows flux in the fingertip skin recorded by the laser Doppler probe A. Lower trace shows pressure in cuff $B$ surrounding the proximal phalanx. At $X$ the cuff was inflated to $200 \mathrm{~mm} \mathrm{Hg}$ and simultaneously the middle phalanx was cooled to $10^{\circ} \mathrm{C}$ by insertion through the perfused cuff $C$ and flux was abolished. After five minutes cooling, gradual cuff deflation commenced at $Y$ and flux returned at $Z$ at a pressure of $102 \mathrm{~mm} \mathrm{Hg}$. Part of the recording during cooling and occlusion between $X$ and $Y$ has been omitted.

exhibited cold induced digital vasospasm similar to that shown in fig 3. After three hours of work the results were unchanged (fig 4 ). So the incidence of cold-induced vasospasm in riveters $(35 \%)$ was significantly higher $(\mathrm{p}<0.001)$ than in matched control subjects $(2 \%)$ and remained unaltered after a morning's work. The occurrence of vasospasm after cooling was not closely correlated with the duration of exposure to vibration, age, or smoking habit ( $r=0.40,0.43$, and 0.18 respectively).

Table 3 shows the mean values for all the measurements made in the riveters and their controls before and after work. Only the FSP after cooling was significantly different $(p<0.001)$ in riveters and control subjects. There was no significant difference between the riveters and control subjects in any of the other measurements before work. There was also no significant difference in any of the measurements after a morning's work.

FIRST STUDY: FURTHER ANALYSIS OF RIVETERS Table 4 shows the 64 riveters divided into three groups on the basis of the actual nature of their work. The groups were well matched for age and duration 


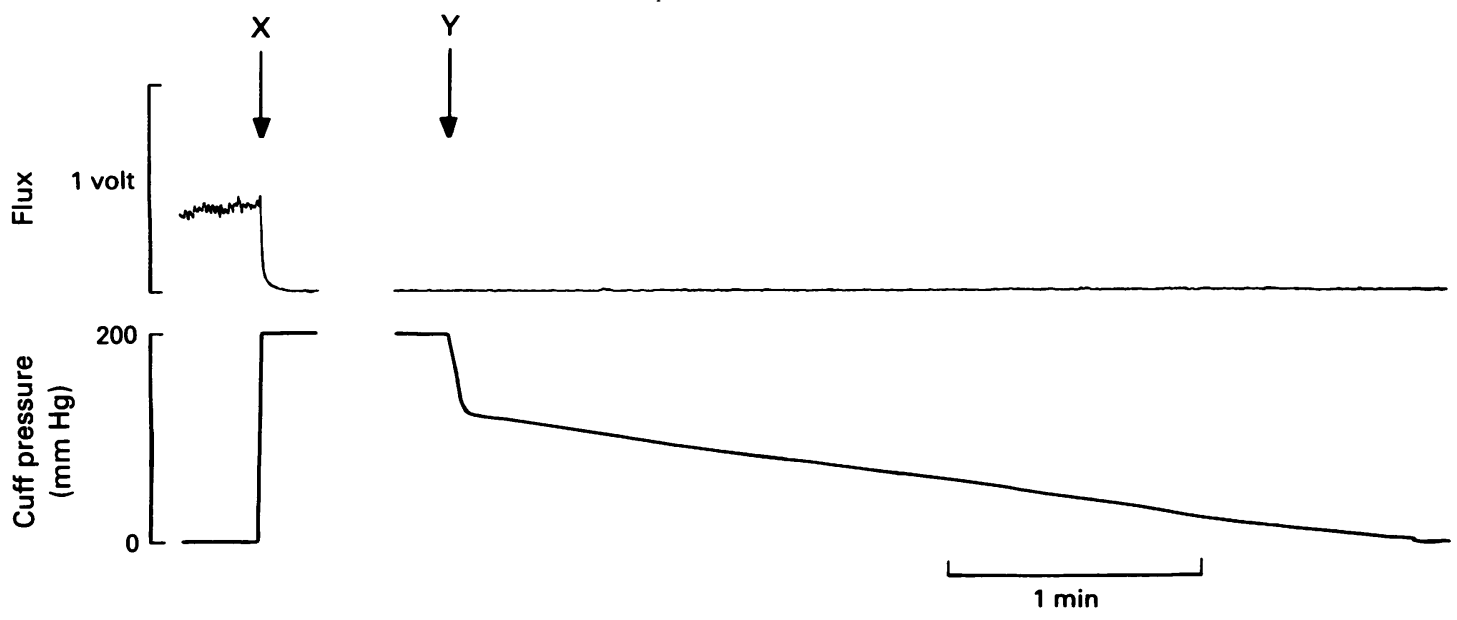

Figure 3 Measurement of response to cooling in the finger of a riveter who had vasospastic symptoms. Upper trace shows flux in the fingertip skin. Lower trace shows pressure in the proximal cuff. At X the cuff was inflated to $200 \mathrm{~mm} \mathrm{Hg}$ and simultaneously the middle phalanx was cooled to $10^{\circ} \mathrm{C}$ by insertion through a perfused cuff as shown in fig 2 and flux was abolished. After five minutes cooling, gradual cuff deflation commenced at $Y$ but there was no return of flux even when the cuff was completely deflated to zero pressure. Part of the recording during cooling and occlusion between $X$ and $Y$ has been omitted.

of occupational exposure to vibration, but more of the dollymen were heavy smokers. There was a higher incidence of cold induced vasospasm among the dollymen (45\%) than in men who always used the rivet gun (10\%). Men who alternated between both jobs were less affected $(27 \%)$ than those who were always dollymen.

This was reflected in the FSP measurements (fig 5). Resting FSP was always similar in the three groups of men. Both before and after work there was a significant reduction in FSP after cooling in all three groups. After work this decrease was significantly greater $(p<0.05)$ in the dollymen than in the rivet gun holders. The morning's work did not significantly reduce resting FSP or FSP after cooling in any of the three groups. Neither duration of exposure to vibration nor smoking habit were related to the incidence of vasospasm.

\section{SECOND STUDY}

Table 5 shows measurements of endothelial activity in the riveters and control subjects before and after work. The concentrations of ET- 1 were slightly lower $(p<0.05)$ in riveters than in control subjects before work. After a morning's work, there was no significant change in ET-1 concentrations in either riveters or control subjects. Consideration of subgroups in relation to the occurrence of vasospasm following provocating cooling, duration of vibration exposure, smoking habit or particular job performed (dollyman or rivet gun holder) did not alter these findings.

There was no significant difference in the plasma vWFAg concentrations in riveters and controls before work. In riveters there was a small increase (p < 0.05) after a morning's work.

Activity of ACE did not differ between riveters and controls before work, and riveting for a morning did not produce any significant alteration.

\section{Discussion}

Traditionally, a typical history of episodic cold induced blanching of the fingers or symptoms of numbness and tingling have played an important part in the diagnosis of VWF. Since the condition became a prescribed industrial disease in 1985, however, more objective assessment of the presence and

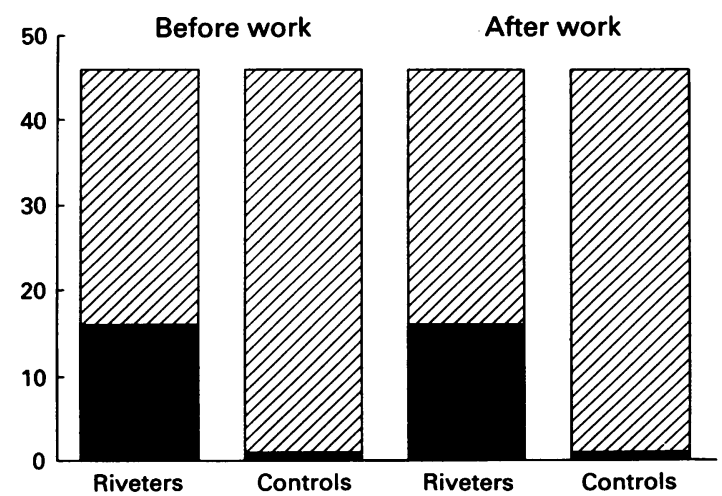

Figure 4 Occurrence of cold induced vasospasm in 46 riveters and 46 matched control subjects before and after a morning's work. Number of men with cold-induced vasospasm; 0 Number of men with no cold induced vasospasm. 
Table 3 Measurements (mean (SEM)) in riveters and control subjects before and after work

\begin{tabular}{|c|c|c|c|c|}
\hline & \multicolumn{2}{|c|}{ Riveters $(n=46)$} & \multicolumn{2}{|c|}{ Controls $(n=46)$} \\
\hline & Before work & After work & Before work & After work \\
\hline $\begin{array}{l}\text { Resting FSP }(\mathrm{mm} \mathrm{Hg}) \\
\text { FSP after cooling } \\
\text { Brachial BP }\left(\mathrm{mm}^{2} \mathrm{Hg}\right) \\
\text { Finger skin temp }\left({ }^{\circ} \mathrm{C}\right) \\
\text { Mouth temp }\left({ }^{\circ} \mathrm{C}\right) \\
\text { Vibration M-C/P joint } \\
\text { PI-P joint } \\
\text { Pulp } \\
\text { Factory temp }\left({ }^{\circ} \mathrm{C}\right) \\
\text { Early morning temp }\left({ }^{\circ} \mathrm{C}\right)\end{array}$ & $\begin{array}{r}112.0(3.3) \\
77.0(7 \cdot 0) \\
125 \cdot 0(2 \cdot 0) \\
27.5(0 \cdot 6) \\
36.3(0 \cdot 1) \\
4 \cdot 8(0 \cdot 3) \\
4.3(0 \cdot 3) \\
3.9(0 \cdot 2) \\
15 \cdot 1(0 \cdot 2) \\
6.7(0.5)\end{array}$ & $\begin{array}{r}111.0(1.9) \\
74.0(7.2) \\
124 \cdot 0(1.7) \\
27.6(0.6) \\
36.3(0 \cdot 1) \\
5.1(0.3) \\
4.3(0.2) \\
4 \cdot 1(0.3) \\
16.6(0.4)\end{array}$ & $\begin{array}{r}117 \cdot 0(1 \cdot 7) \\
108 \cdot 0(3 \cdot 2) \\
126 \cdot 0(1 \cdot 6) \\
27 \cdot 3(0 \cdot 5) \\
36 \cdot 2(0 \cdot 1) \\
4 \cdot 4(0 \cdot 2) \\
4 \cdot 3(0 \cdot 2) \\
4 \cdot 1(0 \cdot 2) \\
15 \cdot 6(0 \cdot 2) \\
7 \cdot 4(0 \cdot 3)\end{array}$ & $\begin{array}{r}112.0(1.9) \\
105.0(3.1) \\
125.0(1.9) \\
27.8(0.5) \\
36.1(0.1) \\
4.2(0.2) \\
4.0(0.2) \\
3.8(0.2) \\
16.9(0.2)\end{array}$ \\
\hline
\end{tabular}

All measurements were made at a room temperature of $20-22^{\circ} \mathrm{C}$.

severity of the vasospastic and neurological manifestations has become desirable.

The approach used in this study was a simplified form of a provocative testing system already described $^{6}$ that is essentially a modification of the method described by Nielsen and coworkers. ${ }^{2}$ The FSP is measured when the finger is warm, and again after local cooling of the middle phalanx. The degree of cold stress is increased in a stepwise manner and the measurement repeated until vasospasm is induced as indicated by an FSP of zero. A patient with severe vasospastic disease will exhibit vasospasm with mild cold stress. A patient with mild disease will require more cooling to induce vasospasm. This type of approach has been evaluated in a study of 35 patients with Raynaud's syndrome of non-occupational origin and 40 matched control subjects. ${ }^{6}$ It proved to be both sensitive and specific, with one false negative result in a patient with clinically very mild Raynaud's syndrome and no false positive results in the control subjects. It has also been used in conjunction with clinical assessment in a study of 33 claimants presenting for assessment in connection with compensation claims for VWF. ${ }^{7}$

In the present study, only 30 minutes were available for all the measurements to be made and so the objective test for vasospasm was carried out with only one cold stress; the degree of local finger cooling and the general environmental temperature were those that had identified patients with moderate vasospastic disease in the laboratory. ${ }^{6}$ Due to industrial

Table 4 Subdivision of the riveters into three groups

\begin{tabular}{|c|c|c|c|}
\hline & $\begin{array}{l}\text { Gun holders } \\
(n=20)\end{array}$ & $\begin{array}{l}\text { Dollymen } \\
(n=22)\end{array}$ & $\begin{array}{l}\text { Gun and dolly } \\
(n=22)\end{array}$ \\
\hline Age (y) & 31 (SEM 1.9) & 32 (SEM 1.9) & 31 (SEM 1.7) \\
\hline $\begin{array}{l}\text { Vibration exposure } \\
\text { (range) }(y)\end{array}$ & $5 \cdot 8(0 \cdot 2-17)$ & $7 \cdot 1(0.4-18)$ & $5.7(0.4-16)$ \\
\hline $\begin{array}{c}\text { Smokers (No) } \\
(\text { mean }(y))\end{array}$ & $\begin{array}{c}6 \\
12 \cdot 8\end{array}$ & $\begin{array}{c}9 \\
17 \cdot 4\end{array}$ & $\begin{array}{c}7 \\
14 \cdot 0\end{array}$ \\
\hline Spasm before & 2 & 10 & 6 \\
\hline Spasm after work & 4 & 10 & 5 \\
\hline
\end{tabular}

constraints, it was not possible to have an equilibration period, and all the measurements were made on the hands or fingers as the men arrived for work in the morning or as they left the factory floor at lunchtime. The measurements do reflect what is happening in the working environment rather than in the artificial, although better controlled, conditions of the laboratory, however. No obvious difference was found in resting FSP, vibration perception, or finger skin temperature in the riveters compared with the controls, although 16 riveters but only one control subject exhibited cold induced vasospasm both before and after work.

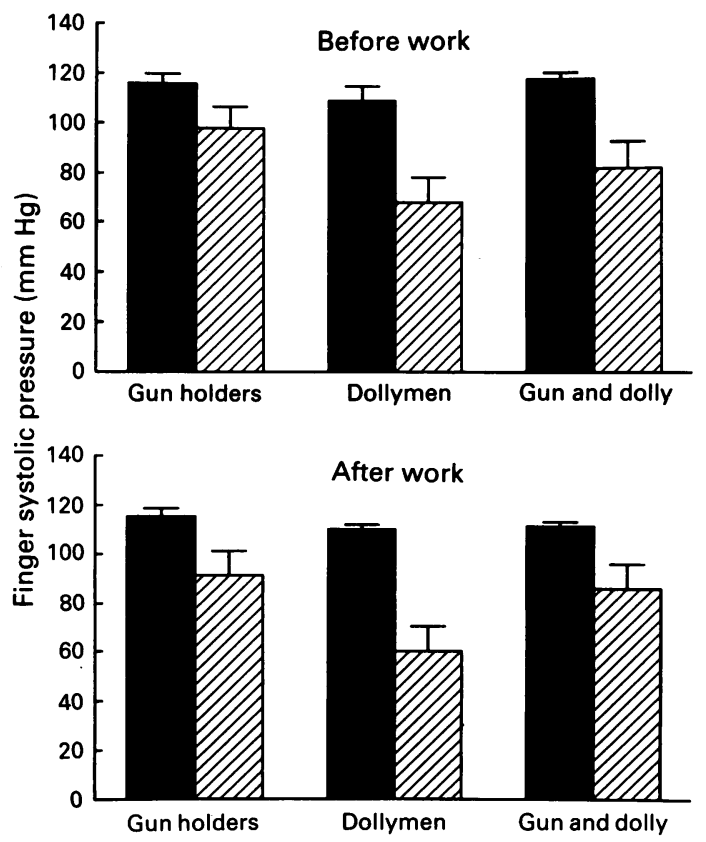

Figure 5 Finger systolic pressure measurements before and after work in rivet gun holders, dollymen, and men who alternate between both jobs. Resting finger systolic pressure with finger in room air; $\mathbb{Z}$ Finger systolic pressure after five minutes middle phalangeal cooling to $10^{\circ} \mathrm{C}$. 
Table 5 Plasma endothelial cell acitivity (mean (SEM)) in riveters and control subjects before and after work

\begin{tabular}{|c|c|c|c|c|}
\hline & \multicolumn{2}{|c|}{ Riveters $(n=25)$} & \multicolumn{2}{|c|}{ Controls ( $n=24$ ) } \\
\hline & Before work & After work & Before work & After work \\
\hline $\begin{array}{l}\mathrm{ET}-1(\mathrm{fmol} / \mathrm{ml}) \\
\text { vWFAg }(\mathrm{IU} / 100 \mathrm{ml}) \\
\mathrm{ACE}(\mathrm{U} / \mathrm{ml})\end{array}$ & $\begin{array}{l}5 \cdot 7(0 \cdot 3)^{2} \\
74 \cdot 7(5 \cdot 0)^{c} \\
28 \cdot 0(8 \cdot 0)\end{array}$ & $\begin{array}{c}6 \cdot 0(0 \cdot 4) \\
81 \cdot 6(5 \cdot 4)^{d} \\
30 \cdot 0(6 \cdot 0)\end{array}$ & $\begin{array}{r}7.0\left(0.5^{b}\right. \\
82.8(6 \cdot 0) \\
32 \cdot 0(9 \cdot 0)\end{array}$ & $\begin{array}{l}6 \cdot 4(0 \cdot 4) \\
92 \cdot 7(6 \cdot 7) \\
34 \cdot 0(10 \cdot 0)\end{array}$ \\
\hline
\end{tabular}

$\mathrm{a} v \mathrm{~b} ; \mathrm{c} v \mathrm{~d}$ significantly different, $\mathrm{p}<0.05$.

Many surveys have reported a high incidence of vasospastic disease in men using pneumatic vibrating tools $s^{15-18}$ and these findings have been confirmed by objective measurements in various groups of workers exposed to vibration. ${ }^{19-21}$ Thus the present findings that riveters had a much higher incidence of cold induced vasospasm than controls agrees with the findings of other workers. In our present study, $17 \%$ of the riveters reported symptoms of VWF on verbal questioning. This was lower than the $25 \cdot 3 \%$ reported in a study based on interviews with 340 aircraft workers in Sweden, ${ }^{22}$ and also less than the 35\% incidence of vasospasm provoked by cold testing.

Resting FSP, cold induced vasospasm, vibration perception, or skin temperature were not altered significantly after a morning's riveting. Riveting is an intermittent task, usually in bursts of one to two minutes, and the riveters themselves thought they experienced roughly 60 to 90 minutes of vibration during the morning. The riveters all came from one centre in which the heaviest riveting in the factory was carried out and the measurements after work were normally started within five minutes of downing tools. It is still possible that transient circulatory effects may have been missed, but the situation in the digital circulation seems rather different from the noise induced hearing loss to which these workers are also prone. ${ }^{23}$ In this condition there is a temporary threshold shift immediately after noise exposure that may become permanent if exposure continues unchecked. ${ }^{24}$ There have been no other studies of this nature on the acute vascular effects of riveting in the work situation as far as we are aware.

Closer investigation of the work done by individual riveters showed that they fell into three subgroups-rivet gun holders, dollymen, and men who alternated between both jobs. The finding that sold induced vasospasm was more prevalent in the dollymen confirmed the subjective impression of the occupational health personnel in the factory. Dollymen have to grip the bar firmly, exerting a strong force on it if the riveting process is to be effective, and so this finding is in agreement with the report that workers who grip firmly around a tool handle are more prone to develop symptoms of VWF. ${ }^{25}$ This has implications for work practice, suggesting that all the riveters should be encouraged to rotate regularly between using the rivet gun and holding the dolly bar.

This type of assessment might be helpful in the pre-employment screening of subjects and also in the detection of those who have developed vasospastic disease. Once it has reached a certain severity, this condition may not regress when exposure to vibration ceases. ${ }^{2627}$

The underlying mechanisms in VWF are not well understood. Prolonged exposure to vibration may cause damage to the autonomic nervous system or to the blood vessels themselves, or it may affect endothelial release of vasoactive factors. In view of the current interest in regulators of blood vessels derived from endothelium, a possible role for three substances was investigated. The potent vasoconstrictor ET1 is synthesised in the endothelium ${ }^{28}$ and its concentrations in blood have been reported to be increased in patients with Raynaud's syndrome compared with controls. ${ }^{8}$ Furthermore, ET-1 concentrations are reported to increase more in Raynaud's patients than controls after cold challenge, ${ }^{8}$ although this has since been disputed. ${ }^{29}{ }^{30}$ In the present study, the early morning plasma concentrations of ET-1 in the riveters were slightly lower than in the control subjects, but a morning's riveting did not alter the concentrations significantly.

Concentrations of vWFAg are raised in inflammatory and non-inflammatory vascular disease ${ }^{9031}$ suggesting that it may reflect the endothelial injury common to these conditions. ${ }^{3132}$ The slightly increased concentrations of this factor in the riveters after a morning's work seem unlikely, however, to imply a major degree of vascular insult. Moreover, this increase did not occur specificially in the men who exhibited cold induced vasospasm, nor was it more pronounced in the dollymen than in the other subgroups of riveters.

Activity of ACE was unaffected by riveting, possibly because the assay was not sufficiently sensitive to detect small changes, or because the endothelium was insufficiently stressed to induce release of this membrane bound ectoenzyme. Concentration of vWFAg is likely to be a more sensitive predictor of insult as it is stored in large amounts in intracellular deposits (Wiebel-Palade bodies). ${ }^{33}$

In conclusion, it proved possible to carry out a 
simple type of objective assessment for cold induced vasospasm under industrial conditions and this confirmed a much higher incidence of the condition in riveters than matched controls. It was also possible to identify a subgroup of riveters who seemed to be at a greater risk of developing this condition. The measurement of the plasma concentration of ET-1 and vWFAg and activity of ACE did not seem to be particularly helpful in this situation although this may be related to the short delay before venous blood sampling was possible or to the intermittent nature of riveting.

We are grateful to the Health and Safety Agency for Northern Ireland and to $\mathrm{Dr} J \mathrm{G}$ Hall and the Employment Medical Advisory Service for their financial support. We thank Mr W Leahy, Department of Therapeutics and Pharmacology, the Queen's University of Belfast, for performing the ET-1 assays and Dr J D Allen for his help in the second study.

Requests for reprints to: Dr J A Allen, School of Biomedical Science (Physiology), The Queen's University of Belfast, Medical Biology Centre, 97 Lisburn Road, Belfast BT9 7BL.

1 Loriga G. II lavoro con i martelli pneumatici. Bollettino Ispettorato del Lavoro 1911;2:35-60.

2 Nielsen SL, Lassen NA. Measurement of digital blood pressure after local cooling. J Appl Physiol 1977;43:907-10.

3 Nielsen SL. Raynaud phenomena and finger systolic pressure during cooling. Scand J Clin Lab Invest 1978;38:765-70.

4 Ekenvall $L$, Lindblad LE. Vibration white finger and digital systolic pressure during cooling. Br J Ind Med 1986;43:280-3.

5 Olsen N. Diagnostic tests in Raynaud's phenomena in workers exposed to vibration: a comparatine study. $\mathrm{Br} \mathrm{J}$ Ind Med 1988;45:426-30.

6 Allen JA, Devlin MA, McGrann S, Doherty CC. An objective test for the diagnosis and grading of vasospasm in patients with Raynaud's syndrome. Clin Sci 1992;82:529-34

7 Allen JA, Doherty CC, McGrann S. Objective testing for vasospasm in the hand-arm vibration syndrome. $\mathrm{Br} J$ Ind Med 1992;49:688-93.

8 Zamora MR, O'Brien RF, Rutherford RB, Weil JV. Serum endothelin-1 concentrations and cold provocation in primary Raynaud's phenomenon. Lancet 1990;336:1144-7.

9 Kahaleh MB, Osborn I, LeRoy EC. Increased factor VIII/von Willebrand factor in Scleroderma and Raynaud's phenomenon. Ann Intern Med 1981;94:482-4.

10 Blann AD, Hopkins J, Winkles J, Wainwright AC. Plasma and serum von Willebrand factor antigen concentrations in connective tissue disorders. Ann Clin Biochem 1992;29:67-71.

11 Ikehata $K$, Kawauchi S, Kohno F, Nishiyama M, Ide N. Increased platelet function and von Willebrand factor in vibration syndrome. Tokushima J Exp Med 1980;27:23-8.

12 Caldwell PRB, Seegal BC, Hsu KC, Das M, Soffer RI Angiotensin converting enzyme: vascular endothelium localisation. Science 1976;191:1050-1.

13 Blann AE. Increased circulating levels of von Willebrand factor antigen in smokers may be due to lipid peroxides. Medical Science Research 1991;19:535-6.

14 Holmquist B, Bunning P, Riordan JR. A continuous spectrophotometric assay for angiotensin converting enzyme. Anal Biochem 1979;95:540-8.

15 Bovenzi M, Petronio L, Marino FD. Epidemiological survey of shipyard workers exposed to hand-arm vibration. Int Arch Occup Environ Health 1980;46:251-66.

16 Behrens V, Taylor W, Wasserman DE. Vibration syndrome in workers using chipping and grinding tools. In: Brammer AJ, Taylor W, eds. Vibration effects on the hand and arm in industry. New York: Wiley, 1982:147-55.

17 Starck J, Farkkila $M$, Aatola S, Pyykko I, Korhonen $O$. Vibration syndrome and vibration in pedestal grinding. $\mathrm{Br} J$ Ind Med 1983;40:426-33.

18 Walker DD, Jones B, Ogston S. Occurrence of white finger in the gas industry. Scand JWork Environ Health 1986;12:301-3.

19 Juul C, Nielsen SL. Locally induced digital vasospasm detected after delayed rewarming in Raynaud's phenomenon of occupational origin. $\mathrm{Br} J$ Ind Med 1981;38:87-90.

20 Pyykko I, Farkkila M, Korhonen O, Starck J, Jantti V. Cold provocation tests in the evaluation of vibration-induced white finger. Scand J Work Environ Health 1986;12:254-8.

21 Welsh CL. Digital rewarming time in the assessment of vibration-induced white finger. Scand J Work Environ Health 1986;12:249-50.

22 Engstrom K, Dandanell R. Exposure conditions and Raynaud's phenomenon among riveters in the aircraft industry. Scand $J$ Work Environ Health 1986;12:293-5.

23 Pyykko I, Starck J, Farkkila M, Hoikkala M, Korhonen O, Nurminen $M$. Hand-arm vibration in the aetiology of hearing loss in lumberjacks. $B r J$ Ind Med 1981;38:281-9.

24 Malerbi B. Audiometry. In: Waldron HA, ed. Occupational health practice. London: Butterworths, 1989:245-68.

25 Farkkila MA, Pyykko I, Starck JP, Korhonen OS. Hand grip force and muscle fatigue in the etiology of the vibration syndrome. In: Brammer AJ, Taylor W, eds. Vibration effect on the hand and arm in industry. New York: Wiley, 1982:45-50.

26 Hursh JH. Vibration-induced white finger-reversible or not? A preliminary report. In: Brammer AJ, Taylor W, eds. Vibration effects on the hand and arm in industry. New York: Wiley, 1982:193-7.

27 Futatsuka M, Ueno T, Sakurai T. Follow up study of vibrationinduced white finger in chain saw operators. Br J Ind Med 1985;42:267-71.

28 Yanagisawa $M$, Kurihara $H$, Kimura $S$, et al. A novel potent vasoconstrictor peptide produced by vascular endothelial cells. Nature 1988;332:411-5.

29 Smits $\mathrm{P}$, Hofman H, Rosmalen F, Wollersheim H, Thien $T$. Endothelin-1 in patients with Raynaud's phenomenon. Lancet 1991;337:236.

30 Hynynen $M$, Ilmarinen R, Saijonmaa O, Tikkanen I, Fyhrquist F. Plasma endothelin-1 concentration during cold exposure. Lancet 1991;337:1104.

31 Editorial. Lancet 1988;331:1203-4.

32 Blann AD, Miller JP, Waite M, McCollum CN. Endothelial cell injury in the risk factors of atherosclerosis. Br J Surg 1992;79:367.

33 Ewenstein BM, Warhol MJ, Handin RI, Pober JS. Composition of the von Willebrand factor storage organelle (Wiebel-Palade body) isolated from cultured human umbilical vein endothelial cells. J Cell Biol 1987;104:1423-33.

Accepted 6 April 1992 